\title{
SYNTHESIS OF DEUTERIUM LABELLED PENICILLAMINE AND ITS USE FOR THE ASSIGNMENT OF THE 1 H NMR SPECTRA OF TWO CYCLIC ENKEPHALIN ANALOGS
}

\author{
Henry I. Mosberg*, John R. Omnaas, \\ Kondareddiar Ramalingam, and Ronald W. Woodard* \\ Department of Medicinal Chemistry \\ College of Pharmacy \\ The University of Michigan \\ Ann Arbor, Michigan 48109-1065
}

\section{SUMMARY}

The synthesis of $D, L-\left[4,4^{1}-2 H_{6}\right]$ penicillamine $\left(D, L-\left[{ }^{2} H_{6}\right] P e n\right)$ and its incorporation into the cyclic, disulfide-containing peptides, [D-Pen $\left.{ }^{2}, \mathrm{D}-\left[{ }^{2} \mathrm{H}_{6}\right] \mathrm{Pen}{ }^{5}\right]$ enkephalin (DPDPE) and [ DPen $\left.{ }^{2}, \mathrm{~L}-\left[{ }^{2} \mathrm{H}_{6}\right] \mathrm{Pen}{ }^{5}\right]$ enkephalin (DPLPE), both highly $\delta$ opioid receptor-selective analogs, are described. The deuterium-labelled peptides allowed the assignment of the four Pen methyl group resonances in each of the corresponding unlabelled peptides to specific Pen residues.

Key Words : $\mathrm{D}, \mathrm{L}-\left[4,4^{1}-2 \mathrm{H}_{6}\right]$ penicillamine, 'H-NMR, deuterium labelling, enkephalin analogs, DPDPE, DPLPE

\section{INTRODUCTION}

Many endogenous peptide hormones and neurotransmitters are relatively small, flexible molecules which can utilize their inherent flexibility to interact with different subclasses of receptors which mediate different physiological events and which presumably place different conformational requirements upon the ligand. In order to elucidate the molecular mechanism of action of a particular peptide hormone or neurotransmitter it is necessary to unravel the distinct actions mediated by the individual receptor subclasses and to determine the bioactive conformation of the peptide ligand at each of these receptors. A particularly useful approach toward these ends is the design and synthesis of analogs of the native peptide into which conformational restrictions are incorporated. One benefit of this approach is that the proper choice of conformational restriction can result in an analog capable of assuming the conformational requirements for interaction

\footnotetext{
"To whom correspondence should be addressed. 
with one subclass of receptor but not other subclasses. Such highly receptor-selective analogs can then be used to determine the physiological actions mediated by distinct receptor subclasses. An additional benefit of conformationally restricted analogs is that while the conformational analysis of flexible peptides is hampered by dynamic averaging of conformation-dependent spectroscopic parameters leading to the determination of an average solution conformation of dubious physical or biological significance, more rigid analogs do not share this liability. Thus, a conformationally restricted analog can be expected to assume a more well-defined solution conformation and allow a more reliable extrapolation to the active, receptor-bound conformation. For conformationally restricted, receptor-selective analogs this allows the determination of the bioactive conformation at specific receptor subclasses.

Analogs of the enkephalins, one class of endogenous opioid peptides, provide an example of the benefits of the approach outlined above. Opioid receptor heterogeneity has been amply demonstrated and it is now clear that three distinct opioid receptor subtypes, designated $\mu, \delta, k$, exist $(1,2)$. A number of enkephalin analogs have been reported which display enhanced receptor selectivity relative to the native ligands. Among these highly selective analogs are the cyclic, disulfide-containing compounds, [DPen $\left.{ }^{2}, D-P e n^{5}\right]$ enkephalin (DPDPE) and [D-Pen²,L-Pen $\left.{ }^{5}\right]$ enkephalin (DPLPE), in which Pen, penicillamine is $\beta, \beta$-dimethylcysteine, which display the highest selectivity reported to date for the $\delta$ opioid receptor (3-5). These diastereomeric enkephalin analogs which have the structure:

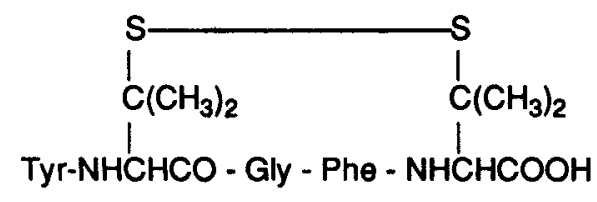

are conformationally restricted due to the imposed cyclization via a disulfide bond and are further conformationally restricted due to the presence of the gem-dimethyl substituents within the 14-membered cyclic moiety (3). Thus DPDPE and DPLPE represent valuable tools for elucidating the active conformation at a specific receptor subtype, the $\delta$ opioid receptor. 
Proton NMR is an extremely powerful method for determining the solution conformation of relatively small peptides such as DPDPE and DPLPE with the obvious first requirement being the assignment of all the resonances within the spectra. In this regard, DPDPE and DPLPE present difficulties. While the $\alpha$-carbon proton resonances arising from Pen ${ }^{2}$ and Pen ${ }^{5}$ can be differentiated by observing chemical shift changes upon $\mathrm{pH}$ titration of the Pen5 carboxylic acid function, the $\beta$ methyl proton shifts are insensitive to this $\mathrm{pH}$ variation. Thus, while four distinct resonances are observed for the penicillamine methyl groups, unequivocal assignment to the individual Pen residues is not possible. In order to remedy this uncertainty, we report here the synthesis of $D, L-[4,4$ -

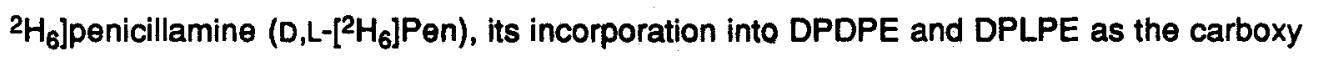
terminal $\left(P^{5}{ }^{5}\right)$ residue, and the subsequent unequlvocal assignment of the Pen methyl 1H-NMR resonances.

\section{EXPERIMENTAL}

Melting points were determined on a Mel-Temp apparatus and are uncorrected. All chemicals were obtained from Aldrich Chemical Co., Vega Biochemicals, and Pierce Co. and were used without further purification. Percent deuterium incorporations were determined from ${ }^{1} \mathrm{H}-\mathrm{NMR}$ spectral data. ${ }^{1} \mathrm{H}-\mathrm{NMR}$ spectra were recorded at $270 \mathrm{MHz}$ on an IBM WP-270-SY NMR spectrometer. Peptide samples for NMR were prepared by first dissolving in $\mathrm{D}_{2} \mathrm{O}$ and lyophilizing to replace exchangeable protons with deuterons and then dissolving in $100.0 \% \mathrm{D}_{2} \mathrm{O}$ and adjusting to $\mathrm{pH} 3.0$ (uncorrected meter reading) with $\mathrm{CD}_{3} \mathrm{CO}_{2} \mathrm{D}$. Chemical shift values are reported in parts per million (ppm) downfield from internal 3-(trimethylsilyl)tetradeuteriopropionate (TSP).

\section{S. Benzyl-D,L-[4,4'-2 $\left.\mathrm{H}_{6}\right]$ penlclllamine.}

A 50-mL three-necked flask, equipped with a magnetic stirring bar, a pressureequalizing addition funnel, and a nitrogen inlet valve was charged with $1.13 \mathrm{~g}$ (0.01 mol) ethyl isocyanoacetate (6) in $10 \mathrm{~mL}$ of freshly distilled tetrahydrofuran and cooled to $-78^{\circ} \mathrm{C}$ while $4.3 \mathrm{~mL}$ of a $2.5 \mathrm{M}$ solution of $n$-butyllithium $(0.011 \mathrm{~mol})$ in THF was added dropwise. After addition of the $n$-butyllithium, the mixture was stirred for $15 \mathrm{~min}$ at $-78^{\circ} \mathrm{C}$, a solution of $\left[{ }^{2} \mathrm{H}_{6}\right]$ acetone $(1.28 \mathrm{~g}, 0.02 \mathrm{~mol}, 99.5$ atom \%) in $5 \mathrm{~mL}$ of THF was added dropwise during a period of $5 \mathrm{~min}$ and the solution was then stirred for an additional $4 \mathrm{~h}$ at $-78^{\circ} \mathrm{C}$. The reaction mixture was allowed to warm to $25^{\circ} \mathrm{C}$ and $1.25 \mathrm{~g}(0.01 \mathrm{~mol})$ of benzyl 
mercaptan was added all at once. After the solution had stirred for an additional $30 \mathrm{~min}$ at $25^{\circ} \mathrm{C}$, the solvent was removed and $15 \mathrm{~mL}$ of a $1 \mathrm{~N} \mathrm{KOH}$ solution was added to the residue. The mixture was stirred until a homogeneous solution was obtained (ca. $30 \mathrm{~min}$ ). The basic solution was neutralized with concentrated hydrochloric acid and allowed to stand at $10^{\circ} \mathrm{C}$ overnight. The precipitated solid was filtered and recrystallized from aqueous ethanol to give $1.51 \mathrm{~g}\left(55.7 \%\right.$ yield) $\mathrm{N}$ - formyl-S -benzyl[4,4'-2 $\left.\mathrm{H}_{6}\right]-\mathrm{D}, \mathrm{L}$ penicillamine, m.p. $156-157^{\circ} \mathrm{C}$ (Lit. (7) m.p. $157^{\circ} \mathrm{C}$ for the nondeuterated analog). ${ }^{1} \mathrm{H}$ NMR (DMSO-d $) \delta 3.28(\mathrm{~s}, 1 \mathrm{H}, \alpha-\mathrm{CH}-), 3.79\left(\mathrm{~s}, 2 \mathrm{H}, \mathrm{C}_{6} \mathrm{H}_{5} \mathrm{CH}_{2}\right), 7.2-7.42\left(\mathrm{~m}, 6 \mathrm{H}, \mathrm{C}_{6} \mathrm{H}_{5-}\right.$ and $\mathrm{CHO}$ merged), 7.52 (bs, $1 \mathrm{H}, \mathrm{NH}$ ).

A solution containing $0.5 \mathrm{~g}$ of the above $\mathrm{N}$ - formyl-S -benzyl[4,4'-2 $\left.\mathrm{H}_{6}\right]-\mathrm{D}, \mathrm{L}$-penicillamine in $10 \mathrm{~mL}$ of $6 \mathrm{~N} \mathrm{HCl}$ was heated under reflux for $12 \mathrm{~h}$. The solvent was removed on a rotary evaporator $\left(45^{\circ} \mathrm{C}\right.$, water aspirator pressure) and the residue was recrystallized from ethanol-diethyl ether to yield $450 \mathrm{mg}(87.5 \%)$ of the title compound hydrochloride salt, m.p. $192-194^{\circ} \mathrm{C}$. The atom percent of deuterium in the product was estimated to be $99 \%$ from the integrated ${ }^{1} \mathrm{H}$-NMR spectra: ${ }^{1} \mathrm{H}-\mathrm{NMR}$ (DMSO-d $\left.{ }_{6}\right) \delta 3.2(\mathrm{~s}, 1 \mathrm{H}, \alpha-\mathrm{CH}$ ) , 3.8 (s, $\left.2 \mathrm{H}, \mathrm{C}_{6} \mathrm{H}_{5} \mathrm{CH}_{2}\right), 7.2-7.4\left(\mathrm{~m}, 5 \mathrm{H}, \mathrm{C}_{6} \mathrm{H}_{5}\right)$.

\section{S- Benzyl-N-t- BoC-D,L-[4, $\left.4^{\circ}-{ }^{2} \mathrm{H}_{6}\right]$ penicillamine.}

The above $S$ - protected amino acid hydrochloride salt $(280 \mathrm{mg}, 1 \mathrm{mmol})$ was dissolved in a solution of dioxane $/ \mathrm{H}_{2} \mathrm{O}(2: 1,7 \mathrm{~mL})$ and $212 \mathrm{mg}(2 \mathrm{mmol})$ of sodium carbonate and cooled to $0^{\circ} \mathrm{C}$ with an ice-water bath. When the evolution of carbon dioxide had ceased, $240 \mathrm{mg}$ of di-tert- butyl dicarbonate $(1.1 \mathrm{mmol})$ was added in portions with stirring. An additional $110 \mathrm{mg}(1 \mathrm{mmol})$ of sodium carbonate in $3 \mathrm{~mL}$ of water was added and the reaction mixture was stirred for $1 \mathrm{~h}$ at $0^{\circ} \mathrm{C}$ and then $12 \mathrm{~h}$ at room temperature. The dioxane was removed on a rotary evaporator. The remaining aqueous solution was acidified ( $\mathrm{pH} \mathrm{6)}$ by the dropwise addition of $2 \mathrm{~N} \mathrm{HCl}$ and extracted with ethyl acetate. The ethyl acetate was washed with water, dried over sodium sulfate and evaporated in vacuo to afford $310 \mathrm{mg}(93 \%)$ of the title compound as a clear oil. ${ }^{1} \mathrm{H}-\mathrm{NMR}$ $\left(\mathrm{DMSO}-\mathrm{d}_{6}\right.$ ) $\delta 1.42\left(\mathrm{~s}, 9 \mathrm{H}, \mathrm{t}-\mathrm{C}_{4} \mathrm{H}_{9}\right), 3.25\left(\mathrm{~s}, 1 \mathrm{H}, \alpha-\mathrm{CH}\right.$ ), $3.82\left(\mathrm{~d}, 2 \mathrm{H}, \mathrm{C}_{6} \mathrm{H}_{5} \mathrm{CH}_{2}\right.$ ), 7.00 (bs, $\left.1 \mathrm{H}, \mathrm{N} H^{-}\right)$, 7.24-7.42 (m, 5H, $\mathrm{C}_{6} \mathrm{H}_{5}-$ ). 
[D-Pen $\left.{ }^{2}, \mathrm{D}-\left[{ }^{2} \mathrm{H}_{6}\right] P e n^{5}\right] e n k e p h a l i n$ and $\left[\mathrm{D}-\mathrm{Pen}^{2}, \mathrm{~L}-\left[{ }^{2} \mathrm{H}_{6}\right]\right.$ Pen $\left.{ }^{5}\right] e n k e p h a l i n$.

The $S$ - Benzyl-N $-t-B O C-D, L-\left[4,4^{\prime}-2 H_{6}\right]$ penicillamine was coupled to chloromethylated ( $1.16 \mathrm{mmol} \mathrm{Cl} / \mathrm{g}$ resin) polystyrene resin $1 \%$ cross-linked with divinylbenzene using the procedure of Gisin (8) and the resin-bound hexadeuterated pentapeptides were synthesized using solid phase methods as previously described (3). Cleavage of the peptides from the resin and simultaneous deprotection of the Pen side chain sulfurs were effected by treatment with anhydrous HF in the presence of $10 \%$ anisole $\left(0^{\circ} \mathrm{C}, 60 \mathrm{~min}\right)$. Extraction of the resin with $80 \%$ acetic acid followed by lyophilization yielded the deuterium labelled, free sulfhydryl-containing peptides which were then oxidized to the cyclic, disulfide-containing forms by treatment with $K_{3} F \theta(C N)_{6}$ as previously described (3). The deuterium-labelled diastereomeric peptides [D-Pen²,D$\left.\left[{ }^{2} \mathrm{H}_{6}\right] \mathrm{Pen}^{5}\right]$ enkephalin and $\left[\mathrm{D}-\mathrm{Pe} \mathrm{n}^{2}, \mathrm{~L}-\left[{ }^{2} \mathrm{H}_{6}\right]\right.$ Pen $\left.{ }^{5}\right]$ enkephalin were separated by high performance liquid chromatography (HPLC) on a Vydac $218 T P$ C-18 column $(2.5 \mathrm{~cm} \times 22$ $\mathrm{cm}$ ) using the solvent system $0.1 \%$ trifluoroacetic acid in $\mathrm{H}_{2} \mathrm{O} / 0.1 \%$ trifluoroacetic acid in acetonitrile (75/25). Analytical HPLC (Vydac 218TP, $0.46 \mathrm{~cm} \times 25 \mathrm{~cm}$ ) of the products showed them to be $>98 \%$ pure and each deuterium-labelled peptide co-eluted with the corresponding unlabelled analog.

\section{RESULTS AND DISCUSSION}

Several chiral glycine-type synthons $(9,10)$ are known that should allow for the asymmetric synthesis of $L-\left[{ }^{2} \mathrm{H}_{6}\right]$ Pen and/or D- $\left[{ }^{2} \mathrm{H}_{6}\right]$ Pen in high optical enrichment $(>98 \%)$. However, since the two diastereomers, DPDPE and DPLPE, are readily separable by HPLC, it was more logical to synthesize $D, L-\left[{ }^{2} H_{6}\right]$ Pen, carry out one solid-phase peptide synthesis and then separate the isomers. The method chosen for the synthesis of $D, L-$ $\left[{ }^{2} \mathrm{H}_{6}\right] \mathrm{Pen}$ involved the use of the glycine synthon, ethyl isocyanoacetate. Perdeuterated acetone was added to the lithiated ethyl isocyanoacetate to give first ethyl 3,3-dimethyl-2hydroxy-2-[3,3-2 $\left.\mathrm{H}_{6}\right]$ isocyanoacetate (a $\beta$-hydroxyvaline analog) which under the reaction conditions used, dehydrated to ethyl 3,3-dimethyl-2-[3,3-2 $\left.\mathrm{H}_{6}\right]$ isocyanoacrylate, a dehydro amino acid derivative. The in situ dehydration was attributed to the acidity of the remaining $\alpha$-hydrogen atom of the monoalkylated ethyl isocyanoacetate. Benzyl mercaptan was added across the double bond giving, after base and acid hydrolysis, the

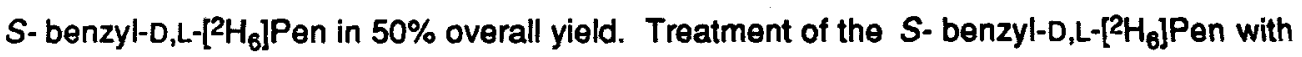


ditert- butyl dicarbonate gave the $S$-benzyl- $N$-tert- boc-D,L-[4,4'-2 $\left.\mathrm{H}_{6}\right]$ penicillamine which was then used to synthesize [D-Pen $\left.{ }^{2}, D-\left[{ }^{2} \mathrm{H}_{6}\right] \mathrm{Pen}^{5}\right]$ enkephalin and $\left[D-\mathrm{Pen}^{2}, \mathrm{~L}-\left[{ }^{2} \mathrm{H}_{6}\right] \mathrm{Pen}^{5}\right]-$ enkephalin via standard solid-phase peptide methodology.

The ${ }^{1} \mathrm{H}-\mathrm{NMR}$ chemical shift values, $\delta$, for the four penicillamine methyl resonances (all singlets) of DPDPE and of DPLPE are shown in Table 1 along with the corresponding chemical shifts observed for $\left[D-P e n^{2}, D-\left[{ }^{2} H_{6}\right] P e n^{5}\right] e n k e p h a l i n$ and $\left[D-P e n^{2}, L-\right.$ $\left.\left[{ }^{2} \mathrm{H}_{6}\right] \mathrm{Pen}{ }^{5}\right]$ enkephalin.

Table 1.

\section{compound}

DPDPE

[D-Pen ${ }^{2}, D-\left[{ }^{2} \mathrm{H}_{6}\right]$ Pen 5 ]enkephalin

DPLPE

$\left[D-P^{2}{ }^{2}, L-\left[{ }^{2} \mathrm{H}_{6}\right]\right.$ Pen $]$ enkephalin

\section{$\delta$-values (Pen methyl sionals)}

$1.48 ; 1.34 ; 1.29 ; 0.84$

$1.48 ; 0.84$

$1.44 ; 1.29 ; 1.27 ; 0.86$

$1.44 ; 0.86$

The results compiled in Table 1 clearly demonstrate that in each of the unlabelled enkephalin analogs the central pair of penicillamine methyl resonances arise from the Pen 5 residue while the downfield-most and upfield-most penicillamine methyl resonances are due to Pen2. It should be noted that more sophisticated NMR techniques, such as two-dimensional COSY optimized to detect long-range coupling constants (11), when applied to the unlabelled peptides were unable to provide this unequivocal assignment (unpublished observation) and thus the judicious use of deuterium-labelled amino acids remains an important tool for the elucidation of ${ }^{1} \mathrm{H}$ NMR spectra of peptides.

\section{ACKNOWLEDGMENT}

This work was supported by U. S. Public Health Service Grant DA 03910 (H. I. M.) and the Program in Protein Structure and Design at the University of Michigan (H. I. M. and R. W. W.). We are grateful to the U. S. P. H. S. and the College of Pharmacy for their contribution to the purchase of the IBM $270 \mathrm{MHz}$ NMR.

\section{REFERENCES}

1. Lord, J. A. H., Waterfield, A. A., Hughes, J. and Kosterlitz, H. W. - Nature 267: 495 (1977). 
2. Paterson, S. J., Robson, L. E., and Kosterlitz, H. W. - Br. Med. Bull. 39: 31 (1983).

3. Mosberg, H. I., Hurst, R., Hruby, V. J., Gee, K., Yamamura, H. I., Galligan, J. J. and Burks, T. F. - Proc. Natl. Acad. Sci. USA 80: 5871 (1983).

4. James, I. F. and Goldstein, A. - Mol. Pharmacol. 25: 337 (1984).

5. Corbett, A. D., Gillan, M. G. C., Kosterlitz, H. W., McKnight, A. T., Paterson. S. J., and Robson, L. E. - Br. J. Pharmacol. 83: 271 (1984).

6. Ramalingam, K., Kalvin, D. and Woodard, R. W. - J. Labelled Compounds, XXI: 833 (1984).

7. Schöllkopf, U. and Hoppe, D. - Angew. Chem. Internat. Edit., 9: 236 (1970).

8. Gisin, B. F. - Helv. Chim. Acta, 56: 1476 (1973).

9. Schöllkopf, U. - Tetrahedron, 39: 2085 (1983).

10. Seebach, D., Boes, M., Naef, R. and Schweizer, W. B. - J. Am. Chem. Soc., 105: 5390 (1983).

11. Bax, A. and Freeman, R. - J. Magn. Resonance $44: 542$ (1981). 